Biol. Proc. Online 1(3), 107-113

\title{
Role of a Transbilayer pH Gradient in the Membrane Fusion Activity of the Influenza Virus Hemagglutinin: Use of the R18 Assay to Monitor Membrane Merging
}

\author{
João Ramalho-Santos ${ }^{1,2}$ and Maria C. Pedroso de Lima ${ }^{3, *}$
}

Center for Neuroscience of Coimbra, University of Coimbra, Portugal. ${ }^{1}$ Department of Zoology, University of Coimbra, Portugal. ${ }^{2}$ Oregon Regional Primate Research Center, Oregon Health Sciences University, Beaverton, OR, USA. ${ }^{3}$ Department of Biochemistry, University of Coimbra, Portugal.

*To whom correspondence should be addressed. Maria C. Pedroso de Lima, Department of Biochemistry, Apartado 3126, University of Coimbra, 3000 Coimbra, Portugal. Phone: + 351 (39) 820190 Fax: 351 (39) 853607 E-mail: mdelima@cygnus.ci.uc.pt

\section{ABBREVIATIONS}

HA- influenza virus hemagglutinin; FCCP- carbonylcyanide-p-trifluoromethoxyphenyl hydrazone; LUV- large unilamellar vesicles; PC- phosphatidylcholine; PE- phosphatidylethanolamine; R18octadecylrhodamine B chloride

\begin{abstract}
It had been suggested that influenza virus-mediated membrane fusion might be dependent on a $\mathrm{pH}$ gradient across a target membrane. We have designed experiments in which this issue could be addressed. Two populations of liposomes were prepared, both simulating the plasma membrane of target cells, but with the $\mathrm{pH}$ of the internal aqueous medium buffered either at $\mathrm{pH} 7.4$ (physiological cytosol $\mathrm{pH}$ ) or at $\mathrm{pH} 5.0$ (endosomal $\mathrm{pH}$ at which influenza virus displays maximal fusion activity). By monitoring fusion using the R18 assay, we found that the internal $\mathrm{pH}$ of the target liposomes did not influence membrane merging as mediated by the influenza virus hemagglutinin, thus demonstrating that a transmembrane $\mathrm{pH}$ gradient is not required in this fusion process.
\end{abstract}

\section{INTRODUCTION}

Influenza virus is a lipid-enveloped virus that enters cells by receptor-mediated endocytosis. Access of viral RNA into the target cell cytosol occurs by fusion of the viral envelope with the membrane of an intracellular compartment (the endosome). This event is mediated by the viral envelope hemagglutinin (HA), and is triggered by conformational changes in HA that take place at the acidic $\mathrm{pH}$ normally found in the endosomal lumen (for recent reviews see 1,2).

C1999 Biological Procedures Online. All rights reserved. Paper-based copying permitted for internal use for educational or non-profit purposes only. Otherwise, this article may be copied to paper provided that \$US15 per copy is paid directly to Biological Procedures Online. Electronic copying, storage or redistribution prohibited. ISSN: 1480-9222

Biological Procedures Online • Vol. 1 No. $3 \bullet$ March 16, 1999•www.biologicalprocedures.com 
Recent publications have demonstrated that influenza virus entry into target cells at low $\mathrm{pH}$ is inhibited when the cell cytosol is acidified $(3,4)$. Similar observations have been made for Semliki Forest virus, a virus that also enters cells by receptor-mediated endocytosis $(6,7)$. It has therefore been proposed that the need for acidic $\mathrm{pH}$ in the entry of influenza virus (and possibly other viruses that share the same pathway) into target cells is more subtle, with the virus requiring not only an acidic (endosomal) environment per se, but a $\mathrm{pH}$ gradient across the target membrane $(3,4,7)$. Productive infection would thus result from the difference between the endosomal lumen $\mathrm{pH}(5.0)$ and the target cell cytosol $\mathrm{pH}$ (7.4). This type of specificity might be relevant in preventing virions from infecting non viable cells (5). More importantly, the observations made with influenza virus led to the intriguing suggestion that the absence of a $\mathrm{pH}$ gradient between the endosome and cytosol resulted in the inhibition of the HAmediated fusion step $(3,4)$. This question could not be settled by re-interpretation of previous data. Indeed, in all studies involving fusion activity of the influenza HA (either using intact viral particles, reconstituted $\mathrm{HA}$ in membranes, or cells that express $\mathrm{HA}$ at their surface) fusion is routinely triggered by lowering the $\mathrm{pH}$ of the reaction medium from $\mathrm{pH} 7.4$ to $\mathrm{pH}$ 5.0. However, compartments sealed by target membranes for the virus (normally liposomes or cultured cells) have an internal aqueous medium which is at neutral $\mathrm{pH}$. Therefore, by designing this type of experiment, one can always imagine the existence of a $\mathrm{pH}$ gradient across the target membrane.

To resolve this issue we conducted experiments in which the putative importance of a transmembrane $\mathrm{pH}$ gradient to the fusion activity of the influenza virus HA might be evaluated. For this purpose fusion was followed by the octadecylrhodamine B chloride (R18) dequenching assay (8-10), using liposomes as target membranes for intact virions. In order to simulate the outer monolayer of a target cell plasma membrane these model membranes were composed of the zwitterionic phospholipids PC and PE, and also included the sialic acid-containing ganglioside GD1a, a molecule known to act as a receptor for the virus $(10,11,15,20)$. Two populations of liposomes were prepared: one encapsulating an aqueous medium at $\mathrm{pH} \mathrm{7.4,} \mathrm{and} \mathrm{one} \mathrm{encapsulating} \mathrm{exactly} \mathrm{the} \mathrm{same} \mathrm{medium,} \mathrm{but} \mathrm{with} \mathrm{its} \mathrm{pH}$ adjusted to 5.0. Virus-liposome fusion is triggered in this system by lowering the $\mathrm{pH}$ of the reaction buffer from neutral to $\pm \mathrm{pH}$ 5.0. However, only when liposomes with an internal $\mathrm{pH}$ of 7.4 are used (i.e., the normal procedure in this type of experiments) will there be a transmembrane $\mathrm{pH}$ gradient across the target membrane. To further pursue this issue we performed experiments using proton ionophores such as FCCP and nigericin, both of which dissipate $\mathrm{pH}$ gradients across membranes (19).

Since it has been shown that liposomes are not always equivalent to biological membranes in the study of viral fusion activity (10), experiments using erythrocyte ghosts (resealed in medium buffered at either $\mathrm{pH} 7.4$ or $\mathrm{pH}$ 5.0) as targets for influenza virus were also performed.

\section{MATERIALS \& METHODS}

Virus, liposome and erythrocyte ghost preparation. Influenza virus, A/PR/8/34 (H1N1) strain, was grown for $48 \mathrm{~h}$ at $37^{\circ} \mathrm{C}$ in the allantoic cavity of 11-day-old embryonated eggs, purified by discontinuous sucrose density gradient centrifugation and stored at $-70^{\circ} \mathrm{C}$ in phosphate buffered saline.

Liposomes (LUVs- large unilamellar vesicles) composed of PC and PE (Avanti Polar Lipids) in a 2:1 molar ratio, and containing $5 \mathrm{~mol} \%$ of the ganglioside GDla (Sigma), were prepared in $85 \mathrm{mM} \mathrm{NaCl}$, $50 \mathrm{mM} \mathrm{KCl}, 1 \mathrm{mM}$ EDTA, $10 \mathrm{mM}$ Hepes, $10 \mathrm{mM}$ Mes, $10 \mathrm{mM}$ sodium citrate, buffered at $\mathrm{pH} 7.4 \mathrm{or}$ 
5.0 by the reverse-phase evaporation method (12). The method involves sonication of a lipid solution in diethylether with the desired encapsulation buffer, followed by ether evaporation. The vesicles were then sized through $0.1 \mu \mathrm{m}$ polycarbonate filters to ensure a homogeneous population, and their concentration determined by a standard phosphate assay, preceded by acid digestion of the phospholipids.

Human erythrocyte ghosts were prepared by the method of Steck \& Kant (18). Following hypotonic lysis at $4^{\circ} \mathrm{C}$ and extensive washes, the membranes were resealed at $37^{\circ} \mathrm{C}$ in $85 \mathrm{mM} \mathrm{NaCl}, 50 \mathrm{mM} \mathrm{KCl}$, $5 \mathrm{mM} \mathrm{MgCl} 2,10 \mathrm{mM}$ Hepes, $10 \mathrm{mM}$ Mes, $10 \mathrm{mM}$ sodium citrate, buffered at $\mathrm{pH} 7.4$ or 5.0.

Viral fusion activity as monitored by the $R 18$ assay. Influenza virus was labeled with octadecylrhodamine B chloride (R18, Molecular Probes Inc., Eugene, OR) as described previously (810). The R18 assay is one of the most common tools to monitor the kinetics of membrane fusion. It involves the spontaneous insertion of the fluorophore (basically a rhodamine moiety attached to a hydrophobic hydrocarbon chain) into the membrane of interest, in this case the viral envelope. Viral incubation with the fluorescent probe takes place in the dark, using a concentration of R18 of $5 \mathrm{~mol} \%$ of lipid, thus ensuring that the fluorophore will be included in the membrane at a selfquenching concentration. Since R18 is solubilized in ethanol, care must be taken to maintain the concentration of this solvent under $1 \%(\mathrm{v} / \mathrm{v})$. The viral-probe mixture was incubated in the dark for 30 min at room temperature. R18-labeled virus was separated from noninserted fluorophore by chromatography on Sephadex G-75 (Pharmacia, Uppsala, Sweden) using $150 \mathrm{mM} \mathrm{NaCl}, 10 \mathrm{mM}$ Hepes, pH 7.4 as elution buffer (labeled virus is included in the column void volume). The protein concentration of the virus was then determined by the Lowry assay.

In all assays using lipid vesicles as target membranes, R18-labeled influenza virus was injected into a cuvette containing liposomes of either population (100 nmoles of LUV lipid per experiment) in a final volume of $2 \mathrm{ml}$. Fusion was monitored continuously at $\mathrm{pH} 5.0$ using the fluorescence dequenching assay as described previously (8-10). In brief, fusion of influenza virus with a target membrane will result in R18 dilution into the new bilayer, which, in turn, will promote a release in probe selfquenching, and a concomitant increase in the fluorescence of the sample.

In some cases the virus was allowed to bind to the target liposomes at neutral $\mathrm{pH}$ before acidification of the medium, and in other assays virus and liposomes were added directly to buffer at pH 5.0. All experiments were carried out at $37^{\circ} \mathrm{C}$ or at $20^{\circ} \mathrm{C}$ using $1 \mu \mathrm{g}$ of viral protein $/ \mathrm{ml}$. The fluorescence scale was calibrated such that the initial fluorescence of R18 labeled virus and LUV suspension was set at $0 \%$ fluorescence. The value obtained by detergent lysis after each experiment with Triton X-100, at a final concentration of $1 \%(\mathrm{v} / \mathrm{v})$, was set at $100 \%$ fluorescence, since maximal dilution of the probe will take place in the presence of detergent. The percentages of dequenching obtained in each experimental curve can thus be considered percentages of membrane fusion activity.

Fluorescence measurements were performed in a Perkin-Elmer LS-50 luminescence spectrometer, with excitation at $560 \mathrm{~nm}$ and emission at $590 \mathrm{~nm}$ (ideal for R18). The sample chamber was equipped with a magnetic stirring device, and the temperature was controlled with a circulating water bath. The initial rate of fluorescence dequenching was calculated following the onset of fusion as the percent of the 
maximum fluorescence increase/min (the slope of a tangent to the fusion curve at its steepest point). The extent of fluorescence dequenching was measured after $5 \min \left(37^{\circ} \mathrm{C}\right)$ or $10 \min \left(20^{\circ} \mathrm{C}\right)$.

Experiments with human erythrocyte ghosts (resealed with medium at $\mathrm{pH} 7.4$ or 5.0) were carried out in basically the same manner. In all cases $1 \mu \mathrm{g}$ of viral protein $/ \mathrm{ml}$ was added to $2 \mathrm{ml}$ of buffer adjusted to $\mathrm{pH} 5.0$ and containing $100 \mu \mathrm{g}$ of target membrane protein $/ \mathrm{ml}$. Membrane fusion, as a function of $\mathrm{R} 18$ dequenching, was monitored for $5 \min \left(37^{\circ} \mathrm{C}\right)$ or $10 \min \left(20^{\circ} \mathrm{C}\right)$.

\section{RESULTS AND DISCUSSION}

In a first set of experiments influenza virus was added to either population of liposomes (with internal aqueous medium buffered at $\mathrm{pH} 7.4$ or 5.0$)$ at $37^{\circ} \mathrm{C}$ and at neutral $\mathrm{pH}$. After a short period $( \pm 1.5 \mathrm{~min})$ to allow virus-liposome binding, the $\mathrm{pH}$ of the reaction medium was adjusted to 5.0, and HA-mediated

TABLE I. Effect of a pH gradient across the target liposomes on the fusion activity of influenza virus. membrane fusion followed by relief of R18 selfquenching (Table I). As seen in the table, there is no significant difference in influenza virus fusion activity towards both types of target membranes. The presence of the proton ionophores FCCP and nigericin also had no visible effect on either the kinetics or the extent of membrane merging (data not shown). It should be noted that internal acidification of viral particles, either by proton ionophores or by the viral envelope M2 protein (a proton

Conditions

Extent of fusion

$(\% \max .)^{\mathrm{d}}$

Initial rate of fusion

$(\% \max . / \min .)^{\mathrm{e}}$

$37^{\circ} \mathrm{C}$

Control (Liposomes pH 7.4)a

Liposomes $\mathrm{pH} 5.0^{\mathrm{b}}$

$37.7 \pm 3.3$

$38.1 \pm 3.0$

$138.0 \pm 14.3$

$141.3 \pm 15.1$

\section{$20^{\circ} \mathrm{C}^{\mathrm{C}}$}

Control (Liposomes pH 7.4)

$46.6 \pm 3.2$

$24.8 \pm 2.2$

Liposomes pH 5.0

$45.7 \pm 2.7$

a Influenza virus $\left(1 \mu \mathrm{g}\right.$ viral protein per $\mathrm{ml}$ ) was added to $2 \mathrm{ml}$ of buffer at $37^{\circ} \mathrm{C}$ and $\mathrm{pH}$ 7.4 containing liposomes prepared in medium at $\mathrm{pH} 7.4$, at a final concentration of $50 \mu \mathrm{M}$ of lipid. Following a short period to allow virus-liposome binding $(1.5 \mathrm{~min})$ the medium $\mathrm{pH}$ was adjusted to 5.0, and R18 dequenching followed for $5 \mathrm{~min}$.

$\mathrm{b}$ Experiments carried out as in (a), but using liposomes prepared in medium at $\mathrm{pH}$ 5.0.

c Influenza virus ( $1 \mu \mathrm{g}$ viral protein per ml) was added to $2 \mathrm{ml}$ of buffer at $20^{\circ} \mathrm{C}$ and $\mathrm{pH}$ 7.4 containing liposomes prepared in medium at $\mathrm{pH} 7.4$ or 5.0 at a final concentration of $50 \mu \mathrm{M}$ of lipid. Following virus-liposome binding $(10 \mathrm{~min})$ the medium $\mathrm{pH}$ was adjusted to 5.0, and R18 dequenching followed for $10 \mathrm{~min}$.

$\mathrm{d}$ Fusion extent measured as a function of R18 dequenching after $5 \mathrm{~min}\left(37^{\circ} \mathrm{C}\right)$ or $10 \mathrm{~min}$ $\left(20^{\circ} \mathrm{C}\right)$ at $\mathrm{pH} 5.0$; results represent the average \pm SD of 3-6 experiments.

e initial rate measured in the first $10-15 \mathrm{~s}$ of the fusion process; results represent the average \pm SD of 3-6 experiments. channel), has been shown to slightly increase the fusion activity of some strains of influenza virus, possibly due to a weakening in the interactions between transmembrane viral envelope proteins and the viral M1 protein, located at the interior of the virion $(13,14)$. However, this effect was not visible in our system. 
Although the process is mediated by target membrane composition, membrane fusion activity of intact influenza virus is generally a very quick and efficient phenomenon at $37^{\circ} \mathrm{C}$, and is essentially complete following the first few seconds after acidification. It is therefore difficult to judge eventual small differences in experimental curves at this temperature. This prompted us to carry out parallel experiments at $20^{\circ} \mathrm{C}$, since fusion is much slower at temperatures below $37^{\circ} \mathrm{C}$ due to a lower mobility of viral fusion proteins $(9,10,15)$.

Although the initial rate of membrane mixing at $37^{\circ} \mathrm{C}$ was much higher, the extent of fusion was larger at $20^{\circ} \mathrm{C}$ (Table I), as was previously noted $(10,15)$. Indeed, this phenomenon has been described before with the same fusion system (15), and has been explained by an interplay between influenza virus fusion activity and viral inactivation, both of which take place at low $\mathrm{pH}$. Thus, if the virus is challenged by low $\mathrm{pH}$ and cannot fuse with a target membrane (either by its absence, or by ineffective viral positioning) it is known to lose its membrane perturbing properties $(9,10,11,16)$. Both fusion and inactivation seem to share a common mechanism, both processes being reduced at lower temperatures $(9,17)$. The drop in the inactivation rate constant with temperature is greater than the drop in the fusion rate constant (9), which results in the virus fusing slower at low temperatures, but more extensively, since inactivation is less significant, although the physiological meaning of this effect remains open to debate $(9,10)$.

However, experiments carried out using both populations of liposomes tested gave essentially the same results as those done at $37^{\circ} \mathrm{C}$, namely, the internal medium of the target membranes did not influence HA-mediated membrane merging (Figure 1, Table I). Also, no difference was determinable if virus and liposomes were prebound at neutral $\mathrm{pH}$ prior to medium acidification, or if they were placed in contact in buffer already adjusted to $\mathrm{pH} 5.0$ (Figure 1).
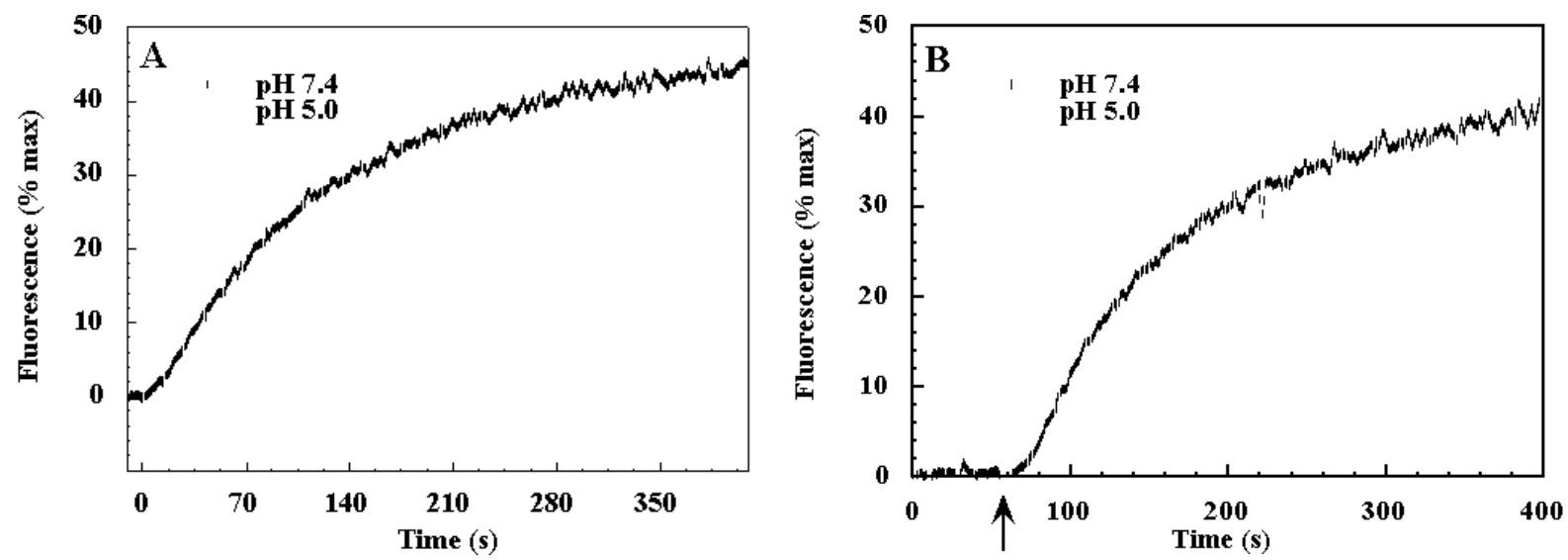

FIGURE 1- Effect of the internal $\mathrm{pH}$ of target liposomes on the fusion activity of influenza virus at $20^{\circ} \mathrm{C}$. R18 labelled influenza virus $(1 \mu \mathrm{g}$ viral protein per $\mathrm{ml})$ was added to $2 \mathrm{ml}$ of buffer at $20^{\circ} \mathrm{C}$. Both populations of liposomes prepared in medium at $\mathrm{pH} 7.4$ or 5.0 at a final concentration of $50 \mu \mathrm{M}$ of lipid were used as target membranes for the virus. A- Virus was added to a lipossome suspension at $\mathrm{pH} 5.0$ and fusion followed as a function of R18 dequenching. B- Following a 10 min incubation at $\mathrm{pH} 7.4$ to allow virus-liposome binding the medium $\mathrm{pH}$ was adjusted to 5.0 (arrow), and fusion monitored as a function of R18 dequenching. Curves represent typical experiments (for statistical significance see Table I). 
Similar observations were made when the same experimental procedure was carried out using biological membranes (erythrocyte ghosts resealed in buffers at different $\mathrm{pH}$ values) as targets for the virus (data not shown). These experiments were undertaken to ensure that the results obtained with liposomes were not a result of the fact that these are artificial bilayers.

When using the R18 assay (or indeed any other membrane fusion assay) the possibility of artifacts must be considered, namely the presence of a "fusion signal" when actual membrane merging did not take place. In the case of our experimental system, unspecific transfer of R18 from the labeled virions to the target membranes could result in a non-relevant increase in fluorescence. To ensure that this does not actually take place we performed the following control experiment: we incubated the virions at $\mathrm{pH} 5.0$ and $37^{\circ} \mathrm{C}$ for $1 \mathrm{~h}$ in the absence of any target membranes. As stated above, such an incubation effectively abolishes (or greatly reduces) influenza virus-mediated membrane fusion $(9,10,11,16)$. Indeed, when these inactivated virions were added to either liposomes or erythrocyte ghosts at $37^{\circ} \mathrm{C}$ and $\mathrm{pH} 5.0$ no fluorescence dequenching was observed in the same time scales as used for the experimental assays (data not shown). This gives us confidence that what we are monitoring with the R18 assay corresponds to actual HA-mediated membrane merging. Although not the case with the data presented here, special attention should be paid to this type of control when membrane fusion activity (i.e. R18 fluorescence dequenching) is very low (less than 10-15\%), or the incubation times necessary to obtain a dequenching signal are very long (over $30 \mathrm{~min}$ ).

Results demonstrate that a $\mathrm{pH}$ gradient across the target membrane is not necessary for influenza virus fusion activity and also that the $\mathrm{pH}$ gradient does not modulate fusion. These findings are contrary to what has previously been proposed $(3,4)$. An eventual block in virus infection following dissipation of the $\mathrm{pH}$ gradient between the virus-containing endosome and cell cytosol cannot be explained by an arrest in membrane merging per se, but may be related to later steps in the process. These could include incorrect delivery of the nucleocapsid into the cytoplasm, lack of proper viral disassembly, or even unforeseen effects of the procedures used to neutralize the $\mathrm{pH}$ gradient (cell cytosol acidification, ionophores and specific inhibitors of endosomal proton pumps) across the target cells themselves. However, it is clear that changes in the membrane fusion activity of the influenza virus HA should not be postulated to explain alterations in overall viral infectivity, since correlation between these two processes may not be linear.

\section{ACKNOWLEDGEMENTS}

This work was supported by PRAXIS XXI, Portugal (PRAXIS/PCNA/P/BIO/45/96) and European Union (BIO4-CT97-2191). J. R.-S. is a recipient of a Praxis XXI postdoctoral fellowship (FCT, Portugal), and received additional financial support from Fundação Luso-Americana para o Desenvolvimento (FLAD, Portugal).

\section{REFERENCES}

1. Hernandez, L. D., Hoffman, L. R., Wolfsberg, T. G. \& White, J. 1996. Virus-Cell and Cell-Cell Fusion. Annu. Rev. Cell Dev. Biol. 12, 627-661.

2. Ramalho-Santos, J. \& Lima, M. C. P. 1998. The Influenza Virus Hemagglutinin: A Model Protein in the Study of Membrane Fusion. Biochim. Biophys. Acta 1376, 147-154. 
3. Guinea, R. \& Carrasco, L. 1994. Concanamycin A Blocks Influenza Virus Entry into Cells Under Acidic Conditions. FEBS Lett. 349, 327-330.

4. Guinea, R. \& Carrasco, L. 1995. Requirement for Vacuolar Proton-ATPase Activity During Entry of Influenza Virus into Cells. J. Virol 69., 2306-2312.

5. Carrasco, L. 1994. Entry of Animal Viruses and Macromolecules into Cells. FEBS Lett. 350, 151154.

6. Helenius, A., Kielian, M., Wellsteed, J., Mellman, I. \& Rudnick, G. 1985. Effects of Monovalent cations on Semliki Forest Virus Entry into BHK-21 Cells. J. Biol. Chem. 260, 5691-5697.

7. Irurzun, A., Nieva, J. L. \& Carrasco, L. 1997. Entry of Semliki Forest Virus into Cells: Effects of Concanamycin A and Nigericin on Viral Membrane Fusion and Infection. Virology 227, 488-492.

8. Hoekstra, D., de Boer, T., Klappe, K. \& Wilschut, J. 1984. Fluorescence Method for Measuring the Kinetics of Fusion Between Biological Membranes. Biochemistry 23, 5675-5681.

9. Ramalho-Santos, J., Nir, S., Düzgünes, N., Carvalho, A. P. \& Lima, M. C. P. 1993. A Common Mechanism for Influenza Virus Fusion Activity and Inactivation. Biochemistry 32, 2771-2779 .

10. Ramalho-Santos, J., Lima, M. C. P. \& Nir, S. 1996. Partial Fusion Activity of Influenza Virus Towards Liposomes and Erythrocyte Ghosts is Distinct from Viral Inactivation J. Biol. Chem. 271, 23902-23906.

11. Stegmann, T., Nir, S. \& Wilschut, J. 1989. Membrane Fusion Activity of Influenza Virus. Effects of Gangliosides and Negatively Charged Phospholipids in Target Liposomes. Biochemistry 28, 1698-1704.

12. Szoka Jr, F. \& Papahadjopoulos, D. 1980. Comparative Properties and Methods of Preparation of Lipid Vesicles (Liposomes). Ann. Rev. Biophys. Bioeng. 9, 467-508.

13. Bron, R., Kendal, A. P., Klenk, H. D. \& Wilschut, J. 1993. Role of the M2 Protein in Influenza Virus Membrane Fusion: Effects of Amantadine and Monensin on Fusion Kinetics. Virology 195, 808-811.

14. Wharton, S. A., Belshe, R. B., Skehel, J. J. \& Hay, A. J. 1994. Role of Virion M2 Protein in Influenza Virus Uncoating: Specific Reduction in the Rate of Membrane Fusion Between Virus and Liposomes by Amantadine. J. Gen. Virol. 75, 945-948.

15. Stegmann, T., White, J. \& Helenius, A. 1990. Intermediates in Influenza Induced Membrane Fusion. EMBO J. 9, 4231-4241.

16. Lima, M. C. P., Ramalho-Santos, J., Flasher, D., Slepushkin, V. A., Nir, S. \& Düzgünes, N. 1995. Target Membrane Sialic Acid Modulates both Binding and Fusion Activity of Influenza Virus Biochim. Biophys. Acta 1236, 323-330.

17. Stegmann, T., Bartoldus, I. \& Zumbrunn, J. 1995. Influenza Hemagglutinin-Mediated Membrane Fusion: Influence of Receptor Binding on the Lag Phase Preceding Fusion. Biochemistry 34, 18251832.

18. Steck, T. L. \& Kant, J. A. 1974. Preparation of Impermeable Ghosts and Inside-Out Vesicles from Human Erythrocyte Membranes. Methods Enzymol. 31, 172-180.

19. Reed, P. W. 1976. Ionophores. Methods Enzymol. 55, 435-454.

20. Suzuki, Y. 1994. Gangliosides as Influenza Virus Receptors. Variation of Influenza Viruses and Their Recognition of the Receptor Sialo-Sugar Chains. Prog. Lipid Res. 33, 429-457. 